\title{
Two new species of Dendrobrachia Brook, 1889 (Cnidaria: Octocorallia: Dendrobrachiidae) from the north-eastern Atlantic and western Mediterranean
}

\author{
PABLO J. LÓPEZ-GONZÁLEZ1 ${ }^{1}$ and MARINA R. CUNHA² \\ ${ }^{1}$ Biodiversidad y Ecología de Invertebrados Marinos, Departamento de Fisiología y Zoología, Facultad de Biología, \\ Universidad de Sevilla, Reina Mercedes 6, 41012 Sevilla, Spain. E-mail: pjlopez@us.es \\ ${ }^{2}$ Centro de Estudos do Ambiente e Mar (CESAM), Departamento de Biologia, Universidade de Aveiro, \\ Campus de Santiago, 3810-193 Aveiro, Portugal. E-mail: marina.cunha@ua.pt
}

\begin{abstract}
SUMMARY: Examination of recent benthic material collected during several cruises in the Gulf of Cadiz (NE Atlantic) and the Strait of Sicily (Mediterranean) has allowed the taxonomic reassessment of some previously identified specimens belonging to the monogeneric gorgonian family Dendrobrachiidae Brook, 1889. Dendrobrachia fallax Brook, 1889 is the type species of the single genus in this family, and was originally described from Ascension Island (South Atlantic). Subsequently, other authors reported the presence of this species in Cape Verde Islands (north-eastern Atlantic) and some Mediterranean localities (Alboran Sea and the Strait of Sicily). The study of the specimen from the Prince of Monaco collections in Cape Verde Islands, and recently collected material from the Gulf of Cadiz (north-eastern Atlantic) and in the south of Malta (Mediterranean), materials previously considered as D. fallax, allow us to recognize two undescribed species in this genus. All previous records of $D$. fallax from the north-eastern Atlantic and Mediterranean should be considered incorrect. Opresko and Bayer (1991) added two additional species of Dendrobrachia. Two new species are described here and compared with their congeners.
\end{abstract}

Keywords: Cnidaria, Octocorallia, Dendrobrachia, north-eastern Atlantic, Mediterranean, new species.

RESUMEN: Dos nuevas ESPECIES DE DENDROBRACHIA Brook, 1889 (CNidaria: Octocorallia: DendrobrachiIdaE) DEL AtLÁNTICo NORESTE y del MediterRáneo ocCidental. - El examen de material bentónico recolectado recientemente en diferentes cruceros en el Golfo de Cádiz (Atántico noreste) y estrecho de Sicilia (Mediterráneo) ha permitido el reemplazamiento taxonómico de algunos especímenes previamente identificados pertenecientes a la familia monogenérica de Gorgona Dendrobrachiidae Brook, 1889. Dendrobrachia fallax Brook, 1889 es la especie tipo del único género de esta familia, y fue originalmente descrito de la isla Ascensión (Atlántico sur). Posteriormente, otros autores citaron su presencia en las islas Cabo Verde (Atlántico noreste) y algunas localidades mediterráneas (mar de Alborán y estrecho de Sicilia). El estudio del especimen de la colección del Príncipe de Mónaco en las islas Cabo Verde, y material recientemente recolectado del golfo de Cádiz (Atlántico noreste) y sur de Malta (Mediterráneo), material previamente considerado como $D$. fallax, nos permiten reconocer dos especies no descritas en este género. Todas las citas previas de $D$. fallax en el Atlántico nordeste y Mediterráneo deben ser consideradas incorrectas. Dos especies adicionales al género fueron añadidas por Opresko y Bayer, 1991. Dos nuevas especies son descritas aquí y comparadas con su congéneres.

Palabras clave: Octocorallia, Dendrobrachia, Atlántico noreste, Mediterráneo, nuevas especies.

\section{INTRODUCTION}

The family Dendrobrachiidae Brook, 1889 is a striking example of difficult taxonomic placement in gorgonians. A general review of the information pub- lished on the single genus Dendrobrachia Brook 1889, initially aligned among the Antipatharia due to the structure of the axis, has already been summarized and discussed by Opresko and Bayer (1991). In that paper, the authors also described two additional species in this 
genus from off the southern coast of Australia and the Strait of Florida.

The type species of the genus Dendrobrachia, $D$. fallax Brook 1889, was described from two colonies collected by the H.M.S. Challenger off Ascension Island (South Atlantic) (see Brook, 1889: 159). Thomson (1910) reported a new finding of Dendrobrachia fallax off Cape Verde Islands, and that specific assignment was subsequently maintained by other authors (Opresko and Bayer, 1991; Zibrowius and Taviani, 2005).

The work of Opresko and Bayer (1991) represented a modification in the uncertain status of the genus Dendrobrachia and family Dendrobrachiidae, with its definitive placement among the octocorals. Furthermore, with the descriptions of two additional species, these authors established the basic characters in the taxonomy of a group of species that lack one of the main octocoral features (the calcareous sclerites) but have an arborescent spiny proteinaceous axis like the members of the hexacorallian order Antipatharia, in which the type species of this genus was initially aligned.

A re-examination of the specimen studied by Thomson, deposited in the Musée Océanographique de Monaco, reveals important differences from the type material of $D$. fallax that allows us to propose a new name for the Cape Verde material.

Recently Zibrowius and Taviani (2005) reported the presence of the genus Dendrobrachia (as D. fallax) from some localities in the western Mediterranean Sea (Alboran Sea and the Strait of Sicily), considerably enlarging the geographical distribution of the type species of this genus.

During some sampling cruises carried out in the Gulf of Cadiz, sponsored by the TTR programme (Training Through Research Programme), a set of colonies attributable to the genus Dendrobrachia were collected. The morphologic study of these colonies showed that they are comparable with the material cited as D. fallax by Zibrowius and Taviani (2005) on the other side of the Strait of Gibraltar, but do not correspond to the characters of the type material of $D$. fallax revised by Opresko and Bayer (1991) nor to the specimen examined by Thomson (1910) from off Cape Verde, considered here an unnamed species. This Dendrobrachia material from the thresholds of the Strait of Gibraltar is considered here as an undescribed species.

The goal of the present contribution is to describe two new species, based on material previously considered under the name of the type species of the genus, Dendrobrachia fallax.

\section{MATERIALS AND METHODS}

The specimen studied here from off Cape Verde was collected by the Prince of Monaco and is part of the collection held by the Musée Oceanographique de Monaco (see Thomson, 1910). The specimens from the Gulf of Cadiz were obtained in a series of TTR cruises carried out on board the RV Prof. Logachev. In these latter cruises, a TV-assisted grab (GR) was used to locate interesting sampling sites in the target environments and a geological dredge (D) was also used on some occasions to recover carbonate chimneys. The biological material obtained was preserved in $70 \%$ or $96 \%$ ethanol. The colonies from south Malta were collected during the MARCOS cruise (ISMAR-CNR, Bologna), on board the RV Urania (6-19 April 2007) in the Strait of Sicily.

Colony terminology mainly follows Bayer et al. (1983) and Opresko and Bayer (1991). The material studied is deposited in the Musée Océanographique de Monaco (MOM), in the Natural History Museum (British Museum) in London (NHM), in the Muséum national d'Histoire naturelle (MNHN) in Paris, in the biological research collection of the Departamento de Biologia, Universidade de Aveiro (DBUA) and in the Anthozoan reference collection of the research group "Biodiversidad y Ecología de Invertebrados Marinos" of the University of Seville (BEIM).

\section{RESULTS}

Family DENDROBRACHIIDAE Brook, 1889
Genus Dendrobrachia Brook, 1889

Dendrobrachia sarmentosa n. sp. (Figs. 1B-H, 2)

Dendrobrachia fallax, Thomson, 1910.

Material examined. Holotype: MOM (INV-21050), 1 colony in alcohol. In label: «St. 1157, 1901, Chaler 219 // vue par Thomson, ANTIPATHARIA, Dendrobrachia fallax».

Diagnostic description of the holotype. Colony planar, about $160 \mathrm{~mm}$ in length, sparsely branched, with a principal axis progressively decreasing in diameter along the length of the colony, and lateral branches irregularly distributed, rarely opposite, highest order branchlets mostly $10-25 \mathrm{~mm}$ long, 0.6-0.9 $\mathrm{mm}$ in diameter, on average about $1 \mathrm{~cm}$ apart on same side of branches. Usually six, occasionally seven axial ridges on branchlets, increasing in number on larger branches. Spines present on ridges, one row per ridge; spines variable in size and shape but increasing in size with increasing thickness of branches, 0.12-0.15 mm long on branches about $1 \mathrm{~mm}$ in diameter. Main axis on third part of the colony $1.6 \mathrm{~mm}$ in diameter with about 14 ridges and spines of $0.12-0.17 \mathrm{~mm}$ in length. Main axis on second part of the colony $2.2 \mathrm{~mm}$ in diameter, with about 20 ridges, and spines of $0.17-0.2 \mathrm{~mm}$ in length. Basal part of the main axis $3.75 \mathrm{~mm}$ in diameter, with about 32-35 ridges and spines of 0.2-0.25 mm in length. Holdfast well developed, elevated, $11 \mathrm{~mm}$ in diameter, covered by spines. Polyps placed bilaterally, alternate or in nearly opposite pairs, 3-5 polyps per $\mathrm{cm}$.

Geographical and bathymetric distribution. Dendrobrachia sarmentosa n. sp. is currently only known 


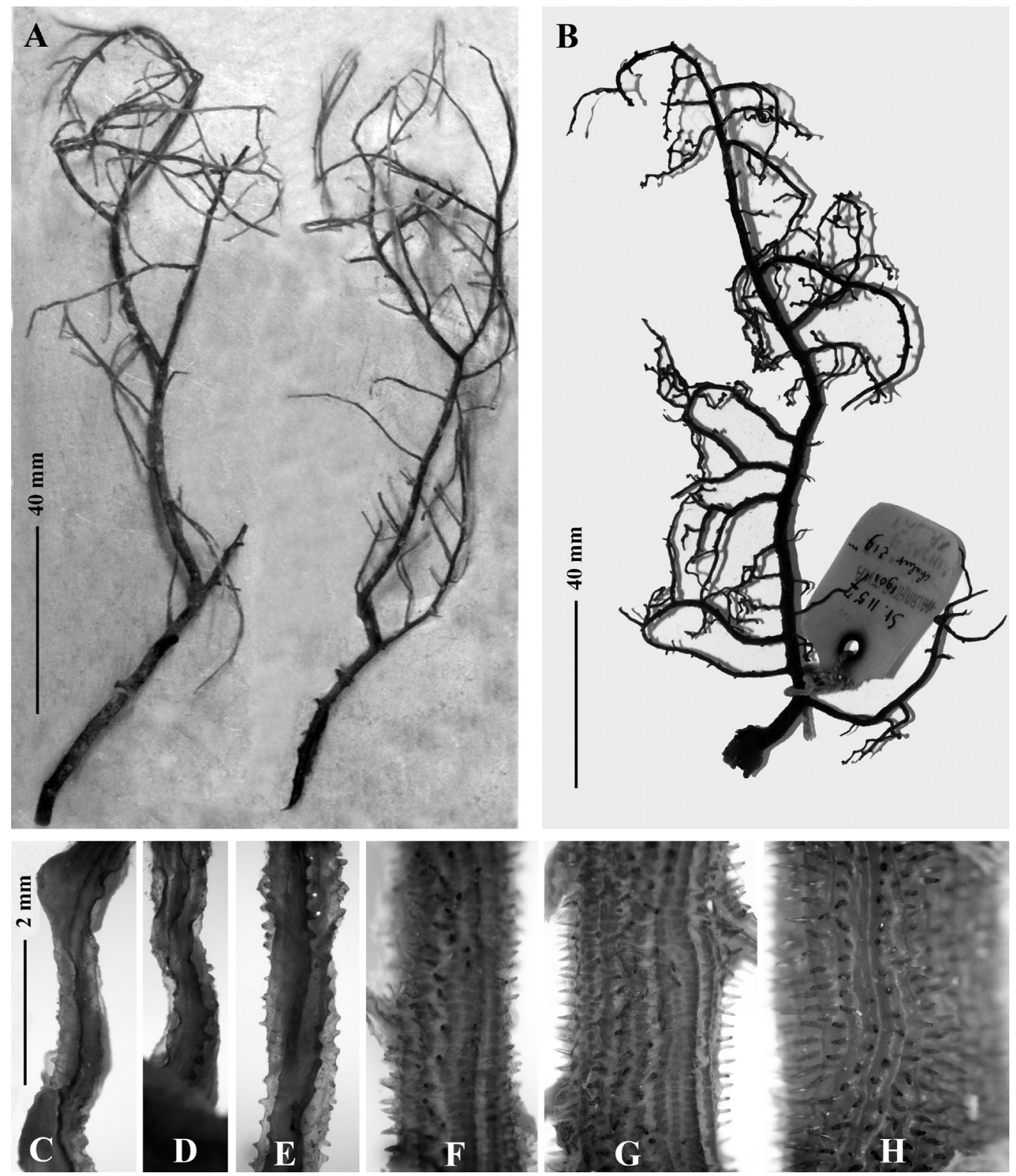

FIG. 1. - Dendrobrachia fallax: A, type material, NHM (1890.4.9.27), the specimen on the right was that illustrated by Brook (1889: plate 10, Fig. 1) (Photo: Emma Sherlock, BMNH, London). Dendrobrachia sarmentosa n. sp., Holotype MOM (INV-21049), specimen initially identified as D. fallax by Thomson (1910): B, complete colony. Spination in D. sarmentosa $\mathrm{n}$. sp. on axial ridges at different levels: C, terminal twig, $0.5 \mathrm{~mm}$ in diameter; $\mathrm{D}$, branch, $0.65 \mathrm{~mm}$ in diameter; E, branch, $0.9 \mathrm{~mm}$ in diameter; F, branch, $1.5 \mathrm{~mm}$ in diameter; $\mathrm{G}, \mathrm{stem}, 2.0 \mathrm{~mm}$ in diameter; $\mathrm{H}$, stem, $2.75 \mathrm{~mm}$ in diameter. Figures $\mathrm{C}$ to $\mathrm{F}$ correspond to branches of different orders on the same side of the main axis. Figures $\mathrm{G}$ and $\mathrm{H}$ correspond to the main axis at mid-distal and proximal levels. Figures $\mathrm{C}$ to $\mathrm{H}$ are at the same scale.

from its type locality, off the island of St. Vincent (Cape Verde Islands), 219 fathoms (about $400 \mathrm{~m}$ ) in depth (see Thomson, 1910 as D. fallax).

Etymology. The specific epithet sarmentosa (Latin for twiggy) refers to the decumbent aspect of the branches and branchlets of this species.

Remarks. The specimen revised here was collected in 1901 by Prince Albert, and assigned by Thomson (1910) to the only known species of Dendrobrachia at that time, D. fallax. Subsequent authors considered that assignation reasonable, and cited the finding in texts (Opresko and Bayer, 1991), but no other re-examination of the material has been carried out until now.

Thomson (1910) indicated in the first lines of his work the reception of four specimens - three dry and one in spirit - from the Prince of Monaco, but only one of these colonies (now in ethanol $70^{\circ}$ ) exists in the deposits of the Musée Océanographique de Monaco (Michèle Bruni, pers. com.). Two of the colonies examined by Thomson had a holdfast, the specimen examined here is apparently one of them. Although we cannot know with certainty the fate of the other 

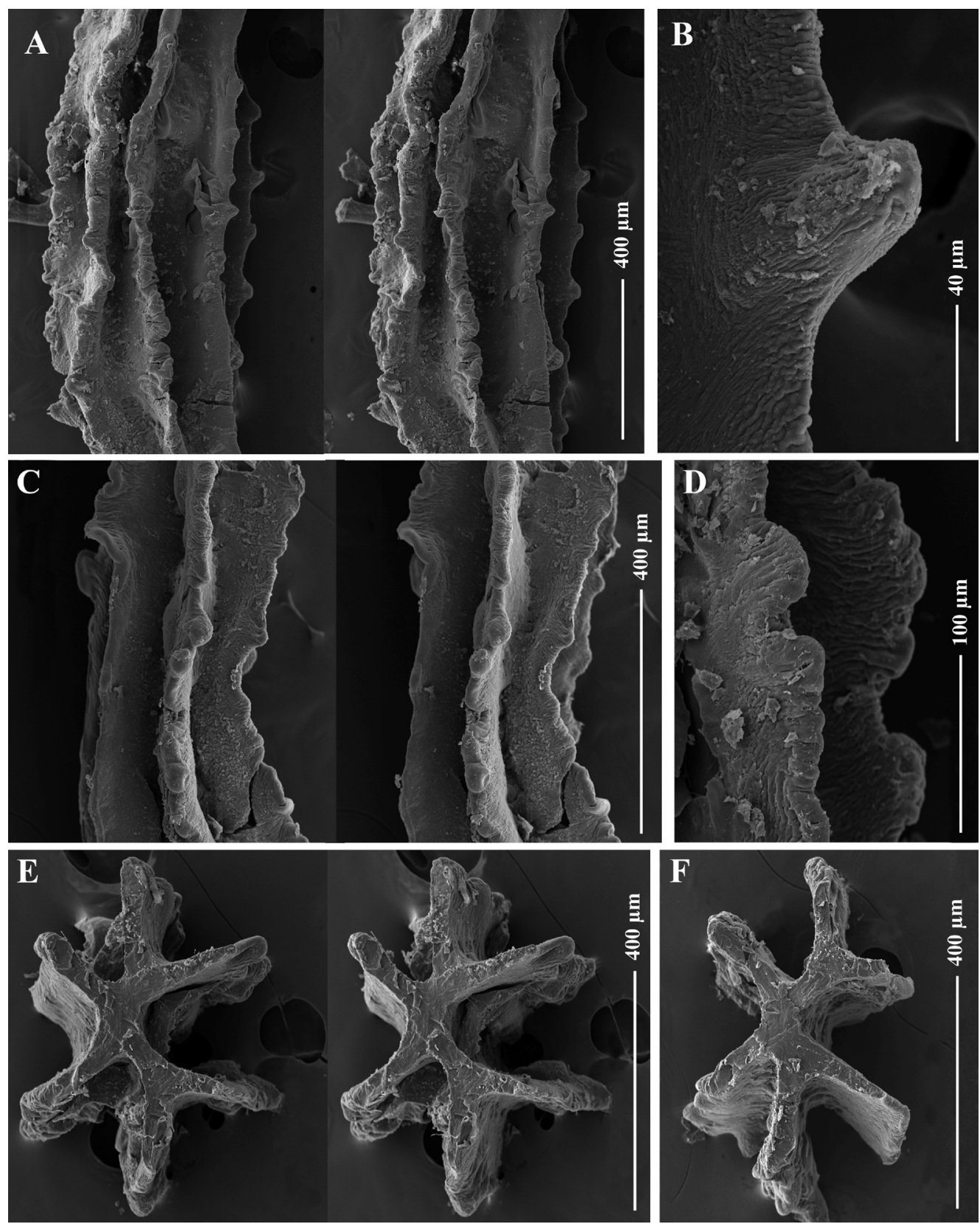

FIG. 2. - Dendrobrachia sarmentosa $\mathrm{n}$. sp. Holotype, MOM (INV-21049). SEM photographs. A, lateral view of terminal twig, stereo pair; B, detail of one of the larger spines on image A; C, lateral view of terminal twig showing low elevations, stereo pair; D, detail of low elevations in C; E, axis, cross section below apex, stereo pair; F, axis, cross section below apex.

specimens, or if the present material was truly that preserved in spirit, the comments made by Thomson - had only a few extremely brittle polyps - and the state and presence of polyps in the colony we examined indicate that this is probably one of the dried colonies that was placed in ethanol later on. An old pencil correction on the registration card of this specimen at the MOM replacing "dried" by "in alcohol" (Michèle Bruni pers. comm.) also supports this hypothesis.

According to the set of characters used by Opresko and Bayer (1991) in the differentiation of Dendrobrachia species, D. sarmentosa $\mathrm{n}$. sp. differs from its congeners in the general branching patterns and angle in which branches (and branchlets) arise from the previous branch order, as well as in the stem diameter / height of corallum ratio, the average distance by which branchlets are separated, and the presence of spines on the axial ridges (see details in Table 1). On this last point, $D$. sarmentosa $\mathrm{n}$. sp. is close to the south-western Australian species $D$. paucispina with respect to the number of rows of axial spines per ridge, and the height of the spines according to the different diameters of the axis. However, as previously mentioned, the branching pattern and angle between branches of contiguous 
Table 1. - Morphometrics for Dendrobrachia spp. (enlarged from Opresko and Bayer, 1991)

\begin{tabular}{|c|c|c|c|c|c|}
\hline Parameter & D. fallax & D. paucispina & D. multispina & D. sarmentosa n. sp. & D. bonsai n. sp. \\
\hline \multicolumn{6}{|l|}{ Corallum: } \\
\hline Stem diam./height (\%) & $1.2-1.5$ & $1.1-1.7$ & $0.7^{\mathrm{a}}$ & 2.5 & $1-1.2$ \\
\hline Holdfast diameter (mm) & --- & --- h & --- & 11 & $2.1-2.5$ \\
\hline \multicolumn{6}{|l|}{ Branchlets: } \\
\hline Maximum length ${ }^{\mathrm{b}}(\mathrm{cm})$ & ca. 3 & ca. 3 & ca. 3 & ca. 2.5 & ca. 2.2 \\
\hline Diameter $(\mathrm{mm})$ & $0.5-0.8$ & $0.4-0.8$ & $0.4-0.5$ & $0.6-0.9$ & $0.15-0.17$ \\
\hline Avg. dist. apart ${ }^{\mathrm{c}}(\mathrm{mm})$ & 9.4 & $9.0-9.5$ & 13 & 5.7 & 10 \\
\hline Angle respect main stem & $>45^{\circ}$ & $>45^{\circ}$ & $>60^{\circ}$ & $80-120^{\circ}$ & $40-70^{\circ}$ \\
\hline \multicolumn{6}{|l|}{ Axial ridges: } \\
\hline Number of branchlets ${ }^{d}$ & (5) $6(7)$ & $6(7,8)$ & 5 & $6(7)$ & (3) 4 \\
\hline \multicolumn{6}{|l|}{ Axial spines: } \\
\hline Number of rows per ridge & 1 & $0-1$ & $1-2+$ & $0-1$ & $0-1\left(2^{\mathrm{m}}\right)$ \\
\hline Max. number per mm per row ${ }^{d}$ & $3-5$ & (3) $4(5)$ & $4(5,6)$ & $3-7(8)$ & 6-8 \\
\hline \multicolumn{6}{|l|}{ Height of spines ${ }^{c}(\mathrm{~mm})$ : } \\
\hline Axis diam. $\leq 0.5 \mathrm{~mm}$ & $0.05-0.10$ & - -- $^{o}$ & $0.06-0.12$ & $0.00-0.02^{j}$ & 0.00-0.03 \\
\hline Axis diam. $0.6-0.8 \mathrm{~mm}$ & $0.10-0.15$ & $0.00-0.07$ & $0.10-0.25$ & $0.01-0.09^{j}$ & $0.00-0.03\left(0.05^{\mathrm{n}}\right)$ \\
\hline Axis diam. $0.8-1.0 \mathrm{~mm}$ & $0.15-0.25$ & $0.07-0.12$ & $0.26-0.32$ & $0.12-0.15$ & 1 \\
\hline Axis diam. $1.0-2.0 \mathrm{~mm}$ & ca. 0.3 & $0.12-0.18$ & $0-25-0.40$ & $0.15-0.18$ & 1 \\
\hline Axis diam. $>2.0 \mathrm{~mm}$ & ca. 0.5 & $0.12-0.25$ & - & $0.17-0.25$ & 1 \\
\hline \multicolumn{6}{|l|}{ Polyps: } \\
\hline Maximum height ${ }^{\mathrm{f}}(\mathrm{mm})$ & 2.5 & 2.2 & ca. 2.3 & $1.75^{\mathrm{i}}$ & $1.4^{\mathrm{i}}$ \\
\hline Number per $\mathrm{cm}$ & $3-6$ & $3-6$ & $3+$ & $3-5$ & $3-4$ \\
\hline Pairs of pinnules & --- & $8-10$ & --- & $6-7 \mathrm{~g}$ & $12^{\mathrm{k}}$ \\
\hline
\end{tabular}

${ }^{\mathrm{a}}$ specimen may be part of a larger colony; ${ }^{\mathrm{b}}$ unbranched branchlets, rarely longer; ${ }^{\mathrm{c}}$ on the same side of the axis; ${ }^{\mathrm{d}}$ rare or exceptional data between parentheses; ${ }^{\mathrm{e}}$ height of spines very variable, commonest size ranges shown; ${ }^{\mathrm{f}}$ including tentacles; ${ }^{\mathrm{g}}$ As reported by Thomson (1910), not clearly observable in present state; ${ }^{\mathrm{h}}$ present in the type material but not described in detail; ${ }^{i}$ preserved material, probably larger in better conditions of conservation. About $2 \mathrm{~mm}$ after Figure 3 in Zibrowius and Taviani (2005); ${ }^{\mathrm{j}}$ from slightly low elevations to short spines; ${ }^{k}$ observed by SEM (Fig. 6A, B), usual inspection by optical microscopy only reveals about $8 ;{ }^{1}$ this axis diameter has not been observed in this species; ${ }^{\mathrm{m}}$ observed in young colonies; ${ }^{\mathrm{n}}$ small colony ( $28 \mathrm{~mm}$ in length), observed at the basal stem; ${ }^{\circ}$ axial diameters $\leq 0.5$ $\mathrm{mm}$ have not been observed in this species; --- no data available.

orders are completely different. Additional details can be observed in Table 1 and selected characters used in the key to species.

\section{Dendrobrachia bonsai n. sp.} (Figs. 3-8)

Dendrobrachia fallax, Zibrowius and Taviani, 2005.

Material examined. Holotype: NHM (2009.9), 1 colony with holdfast, TTR-12 cruise, stn. AT 412-D, Al Idrisi, $35^{\circ} 14.25$ N $06^{\circ} 36.72$ W, 230-235 m, 17 Jul 2002. Paratypes NHM (2009.10-11), 2 colonies. MOM (INV-21898), 1 colony with the same sampling data as the holotype.

Additional material: NHM (2009.12-16), 5 colonies, TTR-12 cruise, stn. AT 388 GR, Formosa Ridge, 36¹0.26'N 7º $43.81^{\prime} \mathrm{W}$, 1079 m, 8 Jul 2002. MON (INV-21899), 5 colonies, TTR-12 cruise, stn. AT 388 GR, Formosa Ridge, $36^{\circ} 10.26^{\prime} \mathrm{N}^{\circ} 43.81^{\prime} \mathrm{W}, 1079 \mathrm{~m}$, 8 Jul 2002. DBUA (01138.02), 38 colonies, TTR-12 cruise, stn. AT 388 GR, Formosa Ridge, $36^{\circ} 10.26^{\prime} \mathrm{N} 7^{\circ} 43.81^{\prime} \mathrm{W}, 1079 \mathrm{~m}, 8 \mathrm{Jul}$ 2002. BEIM (CRO-0019), 20 colonies, TTR-12 cruise, stn. AT 388 GR, Formosa Ridge, 36 $10.26^{\prime} \mathrm{N} 7^{\circ} 43.81^{\prime} \mathrm{W}, 1079$ m, 8 Jul 2002. DBUA (01138.01), 4 colonies, TTR-12 cruise, stn. AT 412-D, Al

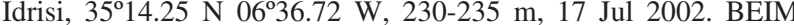
(CRO-0020) 2 colonies, one of them fragmented,TTR-14 cruise, stn. AT-565 GR, Pen Duick, 35¹8.18’N 6 $47.65^{\prime}$ W 544 m, 9 Aug 2004. DBUA (01139.01), 2 colonies, TTR-14 cruise, stn. AT550 D, West of Gibraltar Strait, $35^{\circ} 42.10^{\prime} \mathrm{N} 6^{\circ} 30.19^{\prime} \mathrm{W}, 368-392 \mathrm{~m}, 8$ Aug 2004. MNHN (Oct.2009-0219), 2 colonies, MARCOS cruise, stn 44, south Malta, 35³0.506'N 1406.23'E, 632-467 m, 12 Apr 2007. MNHN (Oct.2009-0220), 18 colonies, MARCOS cruise, sampling data not recorded, but probably close to those of the previous lot.

Diagnostic description of the holotype. Colony planar, about $65 \mathrm{~mm}$ in length, delicate, branched in a nearly dichotomous way, without any branch as prin- cipal axis along the entire length of the colony, main axis before first dichotomy $11 \mathrm{~mm}$ in length, highest order branchlets mostly 5-20 mm long, 0.15-0.17 mm in diameter, on average about $1 \mathrm{~cm}$ apart on same side of branches. Usually four ridges of the branches of higher orders, moderately increasing in number basally. Spines scarce and poorly developed on ridges, when present, one row per ridge; spines variable in size and shape from just a pointed elevation on the ridge to not more than $0.035 \mathrm{~mm}$ high. Axis on distal branchlets is $0.17 \mathrm{~mm}$ in diameter with 4 practically smooth ridges with deep grooves in between. Axis of 0.25-0.3 $\mathrm{mm}$ in diameter, with about 4 ridges, and scarce spines of maximum $0.05 \mathrm{~mm}$. Basal part of the axis, before first dichotomy, is $0.65 \mathrm{~mm}$ in diameter, with about 7-9 wide and rounded ridges, without spines and shallow grooves. Holdfast developed as a small disk, not distinctly elevated, about $1.4 \mathrm{~mm}$ in diameter (possibly larger, partially damaged on one side), without spines. Preserved polyps about $1.4 \mathrm{~mm}$ in height, placed alternately, well separated from one another, between 2.5 and $4 \mathrm{~mm}, 3-4$ polyps per $\mathrm{cm}$. Tentacles with 8-9 pairs of pinnules (probably more, but not correctly observed due to the state of preservation of the soft parts of the colony). Polyps contractile to some degree, but not retractile. Distally some polyps are distinctly mature, developing oocytes with a maximum diameter of up to $0.8 \mathrm{~mm}$.

Variations. In general, the paratypes and the remaining examined material show similar characters to those 

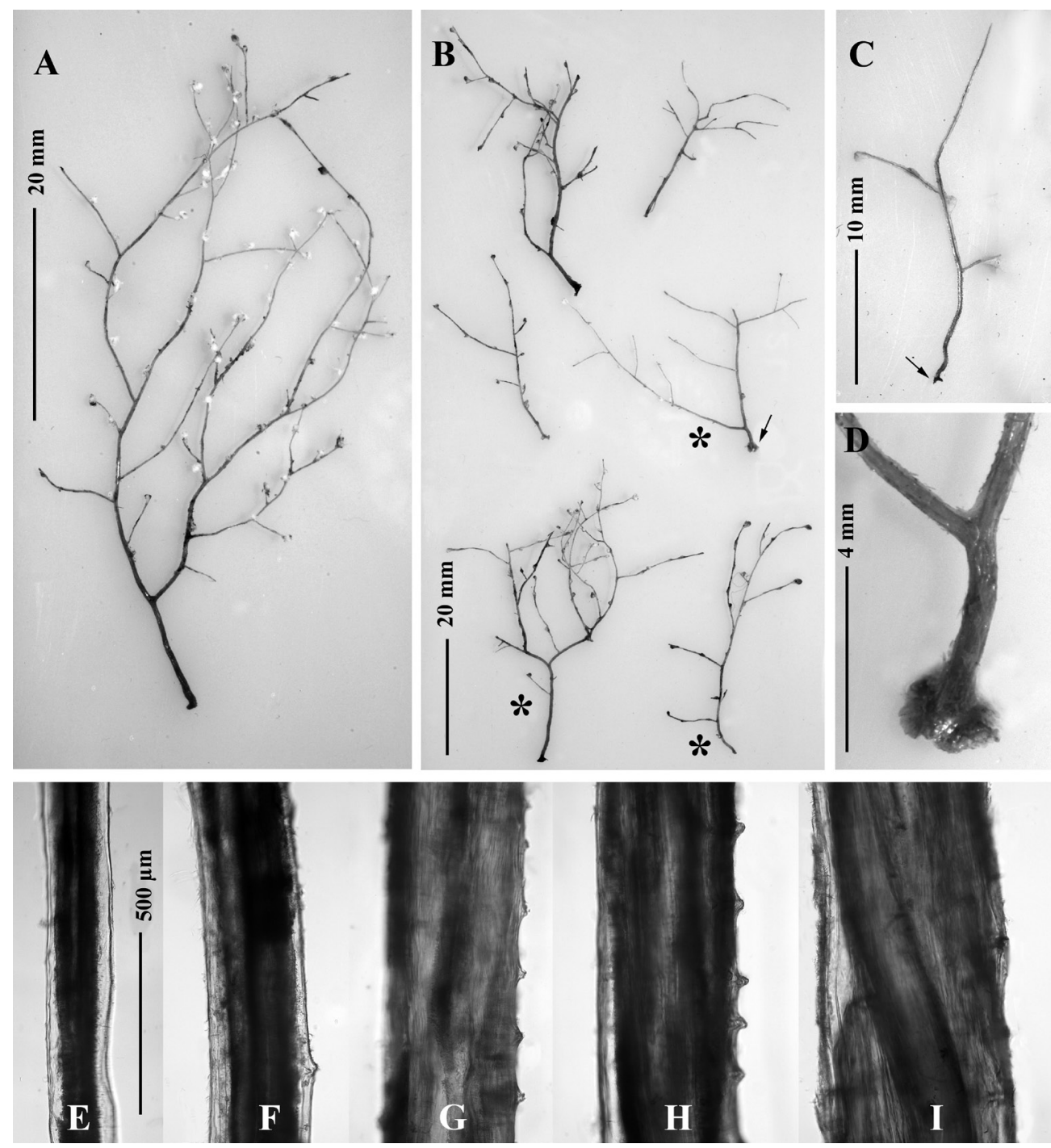

FIG. 3. - Dendrobrachia bonsai n. sp.: A, Holotype, NHM (2009.9), complete colony, $65 \mathrm{~mm}$ in length; B, a set of colonies from station AT412D, showing part of the colonial variability observed, holdfast indicated with an arrow in one of the colonies, the three colonies with asterisk are the paratypes NHM (2009.10-11) MOV (INV-21898); C, BEIM (CRO-0020) complete colony, $28 \mathrm{~mm}$ in length, holdfast indicated with an arrow; D, holdfast from one of the paratypes in B (middle line on the right);. Spination in the holotype of D. bonsai on axial ridges at different levels: $\mathrm{E}, 0.17 \mathrm{~mm}$ in diameter; F, $0.30 \mathrm{~mm}$ in diameter; $\mathrm{G}, 0.37 \mathrm{~mm}$ in diameter; $\mathrm{H}, 0.42 \mathrm{~mm}$ in diameter; and $\mathrm{I}, 0.50 \mathrm{~mm}$ in diameter. Figures $\mathrm{E}$ to $\mathrm{H}$ correspond to branches of different orders on the same side of the main axis. Figure I corresponds to the main axis before the first ramification.

in the holotype in reference to diameter and number of ridges (and ornamentation) in branches and branchlets. The branching pattern seems to be mainly dichotomous, but lateral branches also appear. Some of the shorter colonies (usually smaller than $30 \mathrm{~mm}$ in length) show a monopodial branching pattern, others already have the first main dichotomy distinct. The stem before the first ramification varies from 4 to $17 \mathrm{~mm}$ in length. Complete holdfast disk wider than in the holotype (the latter was probably damaged by collection), from 2.1 to $2.5 \mathrm{~mm}$ in diameter. Up to 10 longitudinal ridges are present on the basal stem of the paratype, the additional material examined shows 6 to 14 in number, depending on total length and diameter. Spination on the main stem before the first ramification varies in the different colonies observed. Although the holotype (65 $\mathrm{mm}$ in colony length) does not have spines, colonies (52 $\mathrm{mm}$ in length) showed scarce spines on a single line no more than $0.03 \mathrm{~mm}$ in length, a colony, $28 \mathrm{~mm}$ in length, showed spines of up to $0.046 \mathrm{~mm}$ in two lines per axial ridge. The number of pairs of pinnules per tentacle has been found in SEM observations to be about 12 (Fig. 6A, B). Optical microscopy observations usually reveal a lower number of pairs, also due to the state of preservation of these soft parts.

SEM and histological observations showed additional information on the structure of the axis and reproductive features. Transverse sections observed by SEM showed a multilayer axial structure (Figs. 5B-D, 7D-F), with layers of variable thickness (Figs. 8 A, B). Histological transversal sections of the axis at different levels showed the thickness of the differ- 

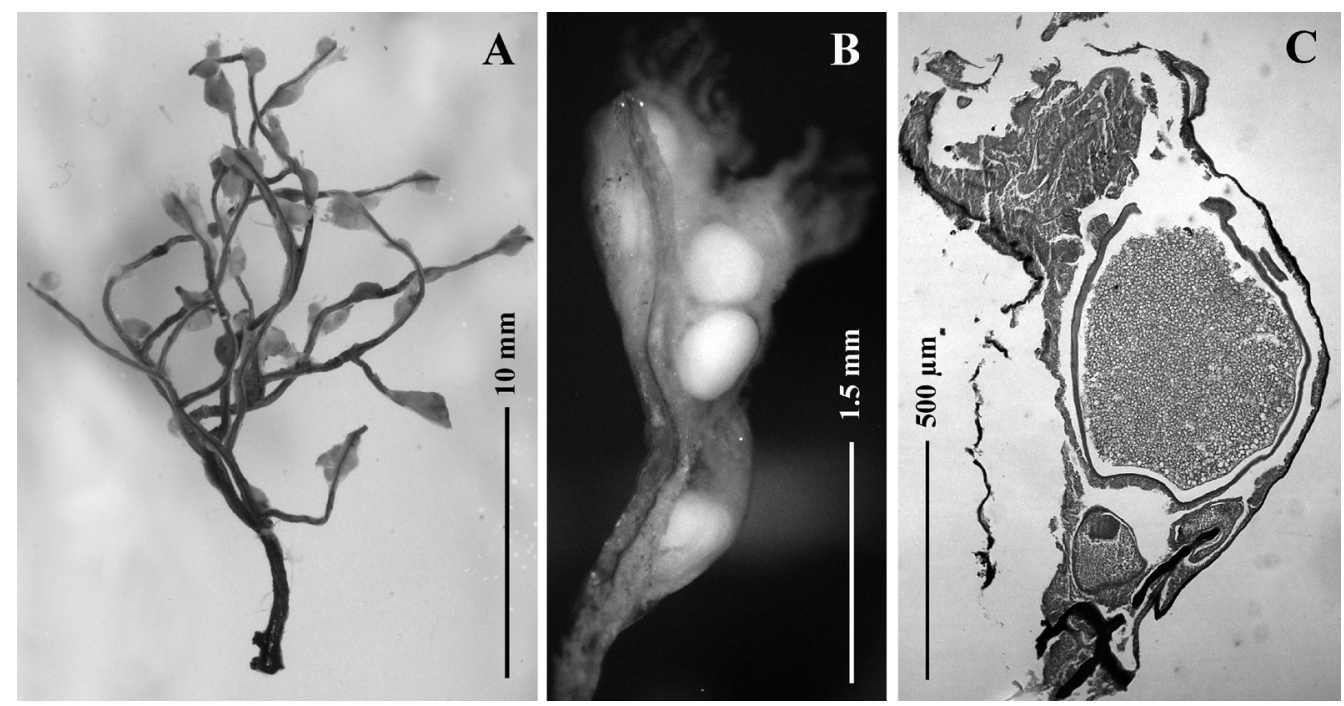

FIG. 4. - Dendrobrachia bonsai n. sp. MOM (INV-21899): A) a complete colony with holdfast, 23 mm in length, showing most of its polyps developing oocytes; B) detail of a terminal twig showing three polyps with oocytes of about $600 \mu \mathrm{m}$. BEIM(CRO-0020): C) histological section of a polyp from a terminal twig showing developing oocytes.
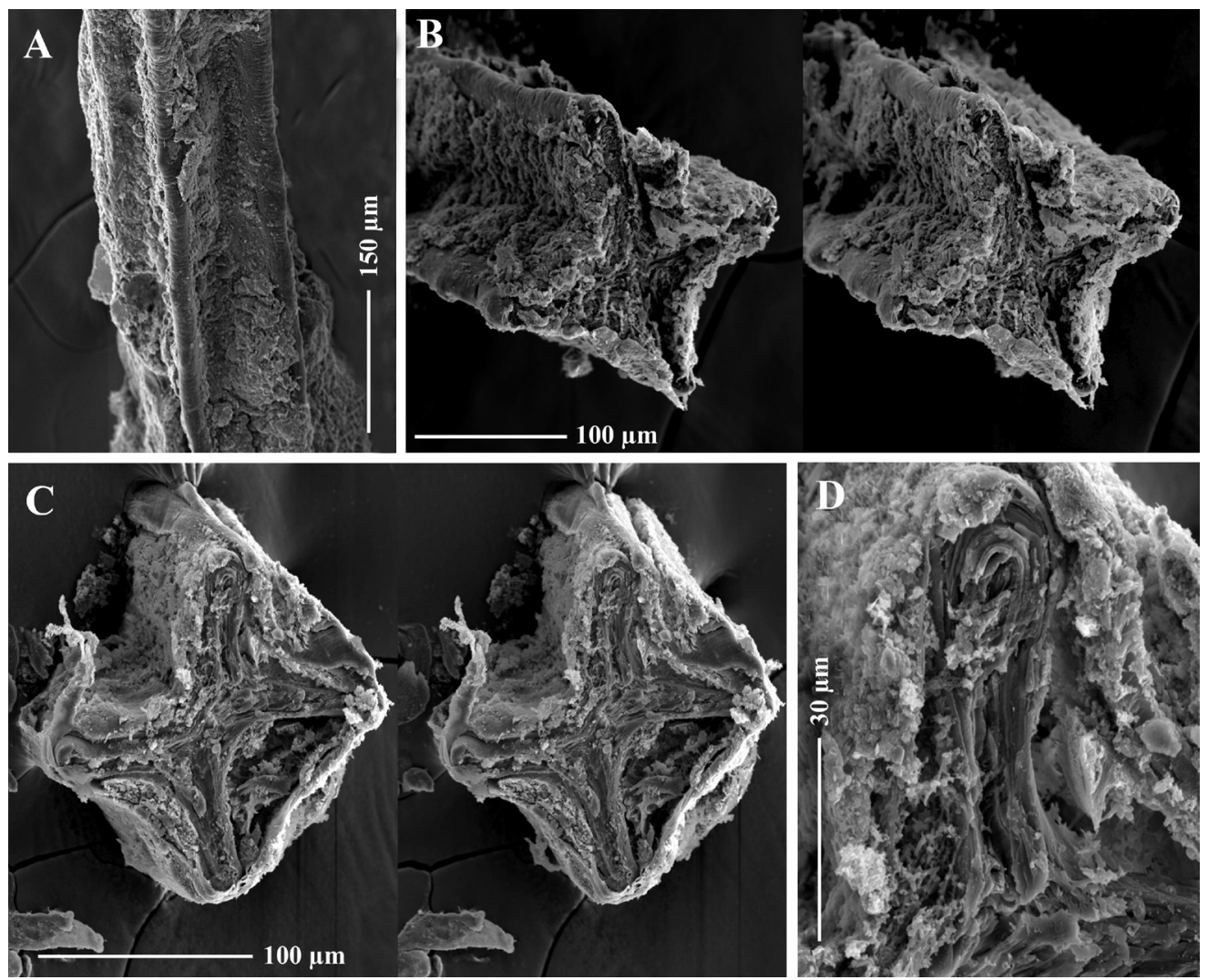

FIG. 5. - Dendrobrachia bonsai n. sp. Holotype, NHM (2009.9): SEM photographs: A, lateral view of terminal twig; B, cross section below apex, showing cruciform outline of the axis, note that coenenchyme is still present in the section, filling the angular spaces between adjacent longitudinal axial ridges, stereo pair; $\mathrm{C}$, axis, cross section of a terminal twig at a lower level than $\mathrm{B}$, note the four axial ridges with a multilayer structure, stereo pair; $\mathrm{D}$, detail of $\mathrm{C}$ showing the numerous layers already present in the axis at the four-ridges state.

ent layers in more detail, and the true shape of the axial nucleus (the most internal part of the axis without multilayer structure, the unique axial structure observable in the most terminal twigs) is 4 ridged (rarely 3 ridged) (see Figs. 8c-e). The number of layers subsequently decreases from the basal stem to the distalmost twigs, where only the central nucleus is present. Transversal sections of the axis near the distal tips of the branchlets show a 2 layer structure (central core plus additional layer). Taking into 

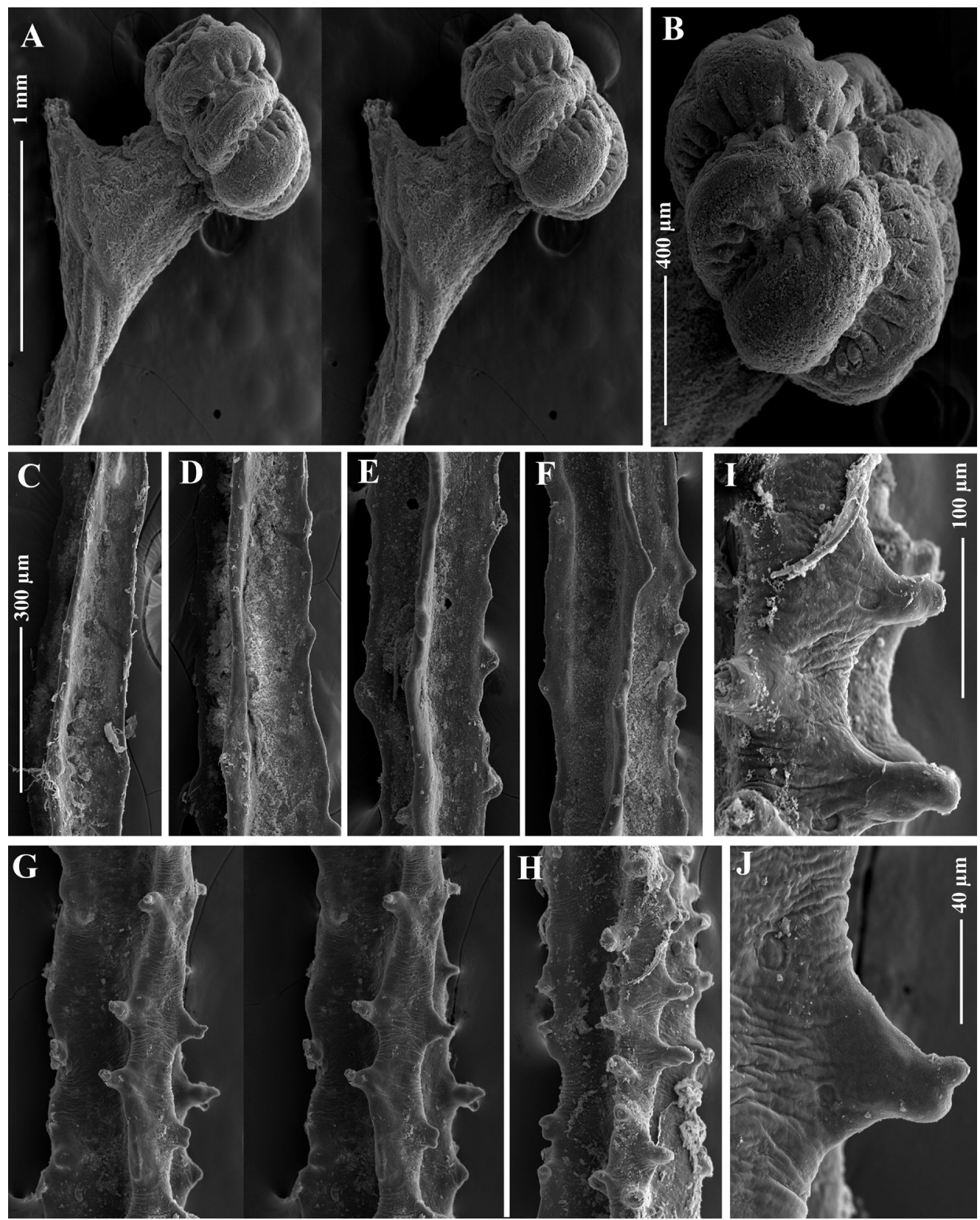

FIG. 6. - Dendrobrachia bonsai n. sp. Colony illustrated in Figure 3C, BEIM(CRO-0020): A, one of the four polyps present in a $28 \mathrm{~mm}$ high colony, showing the column and pinnate tentacles, stereo pair; B, detail of A showing the crown of eight pinnate tentacles; $\mathrm{C}$ to $\mathrm{H}$, lateral view of axis from terminal branchlet $(\mathrm{C})$ to near the basal stem $(\mathrm{G}$ and $\mathrm{H})$, all these figures at the same scale, note the presence of two rows of spines in $\mathrm{G}$ and $\mathrm{H}$; I, detail of $\mathrm{H}$, showing the larger spines arranged in two rows per axial ridge; J, detail of one of the larger spines in $\mathrm{G}$.

account the fact that these specimens are found in temperate latitudes, this 2-layer structure probably indicates a 2-year old branchlet. One of the thicker basal stems sectioned (about $0.67 \mathrm{~mm}$ in diameter) belonging to a colony $42 \mathrm{~mm}$ in length, showed about 25 layers (Fig. 8D,E). SEM and histological sections show how new ridges are added (see Figs. 7E, F; 8D, E). The axial central core has flattened (Figs. 3E; 5A; 6C; 7A) and narrow (in section) ridges (see Fig. 5B; $8 \mathrm{C}$ ). The sequential addition of layers increases the thickness of a ridge, giving initially a distally flat- tened ridge (Fig. 6G, H) with slightly elevated borders, where axial spines can appear. The continuous addition of layers and the increment of ridges can be easily followed in transversal sections by SEM and histological sections.

Apart from the absence of sclerites and the distinct structure of the axis in the species of the genus Dendrobrachia, the known colonies (nearly one hundred) of the new species proposed here do not reach more that $70 \mathrm{~mm}$ in total length, and colonies of about $15 \mathrm{~mm}$ already have polyps with developing gonads of about 

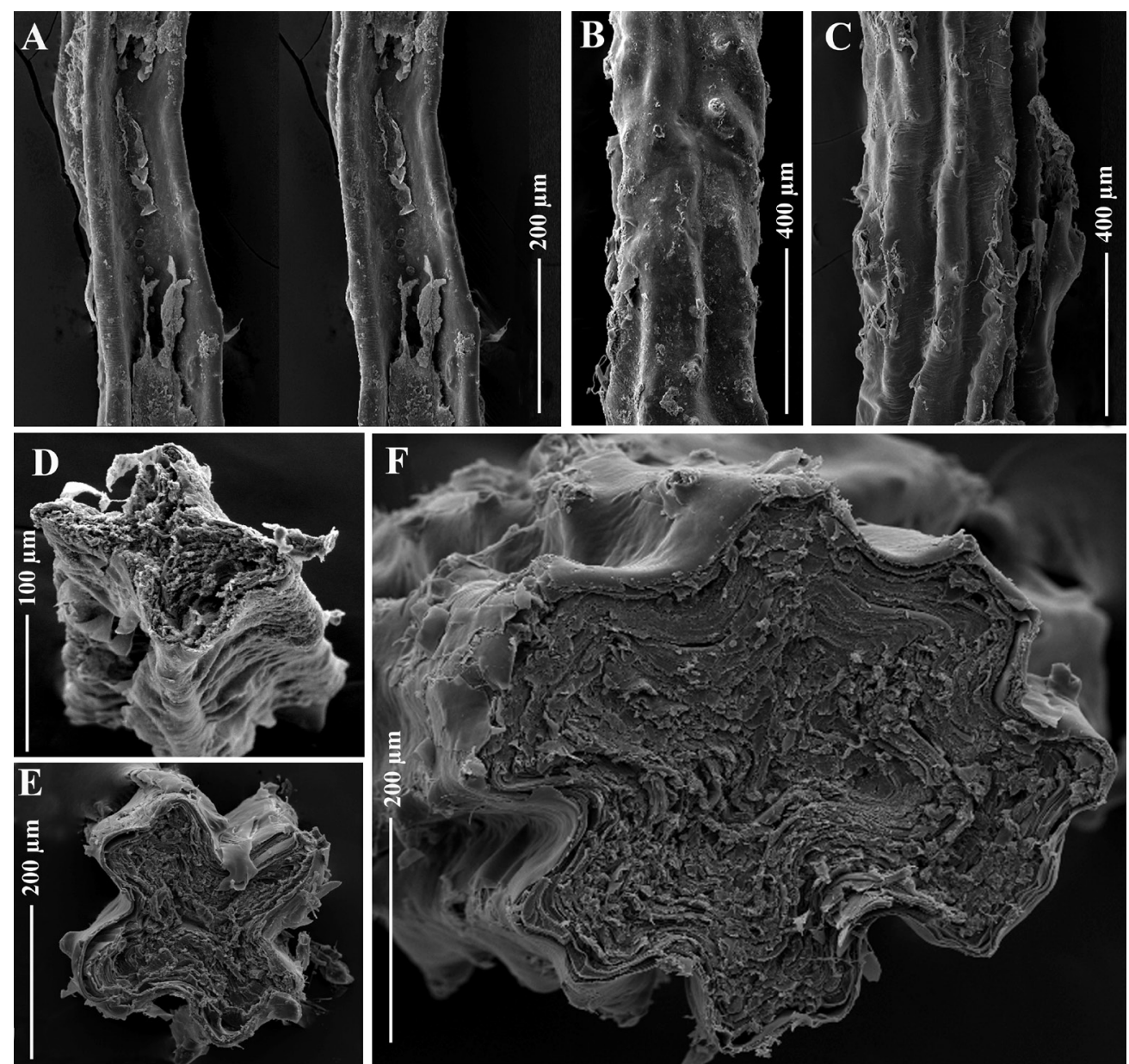

FIG. 7. - Dendrobrachia bonsai n. sp., BEIM(CRO-0019): A, lateral view of axis of terminal branchlet, stereo pair; B, detail of axial surface of a $0.34 \mathrm{~mm}$ basal stem; C, detail of axial surface of a $0.44 \mathrm{~mm}$ basal stem; D, cross section below apex, showing cruciform outline of the axis, note that coenenchyme is still present in the section, filling the angular spaces between adjacent longitudinal axial ridges; E, cross section of a 6-7 ridged axis, note that the increment in ridges is made by the enlargement of a previous ridge, and the multilayered structure of the axis; $\mathrm{F}$, cross section of a 12 ridged axis.

$0.7 \mathrm{~mm}$ (Fig. 4). This is one of the smaller gorgonian species the authors are aware of that reaches a mature state in colonies of such a short length. However, we should take into account the fact that a small size is not necessarily related to a young state or short life span, since, as was mentioned above, about 25 layers can be found at the basal stem level in colonies of $42 \mathrm{~mm}$ in total length.

Geographical and bathymetric distribution. Dendrobrachia bonsai n. sp. is currently known from the Gulf of Cadiz (present account), Alboran Sea and the Strait of Sicily (south of Malta in this paper plus additional localities in Zibrowius and Taviani, 2005 as $D$. fallax) between 230 and $1080 \mathrm{~m}$ in depth (Fig. 5).

Etymology. The specific epithet bonsai refers to the ancient oriental art of miniaturizing plants grown in containers, in allusion to the small and delicate aspect of the colonies of this species in relation to the other species described in the genus Dendrobrachia. Name in apposition.
Ecological observations. In the Gulf of Cadiz Dendrobrachia bonsai n. sp. is presently known from five localities representing three different types of habitat: carbonate chimneys (site west of the Strait of Gibraltar, AT550Gr and Formosa Ridge, AT388Gr and AT389D); dead scleractinean corals (Pen Duick Escarpment, AT406Gr and AT565Gr) and the crater of a mud volcano (Al Idrisi, AT412D).

In Al Idrisi, Dendrobrachia bonsai n. sp. was collected from the numerous sandstones recovered by the geological dredge, and therefore the distribution of the species in the Gulf of Cadiz appears to be limited by the availability of a suitable hard substratum for settlement. The carbonate chimneys, formed inside the sediment by microbial mediation but presently inactive are exposed at the surface of the seafloor by the erosive action of the Mediterranean outflow (Magalhães, 2007), and the video observations (deeptowed TV) carried out during TTR cruises at these sites show evidence of considerable bottom current velocities. These video observations also showed that the faunal assemblage in all sites was clearly domi- 

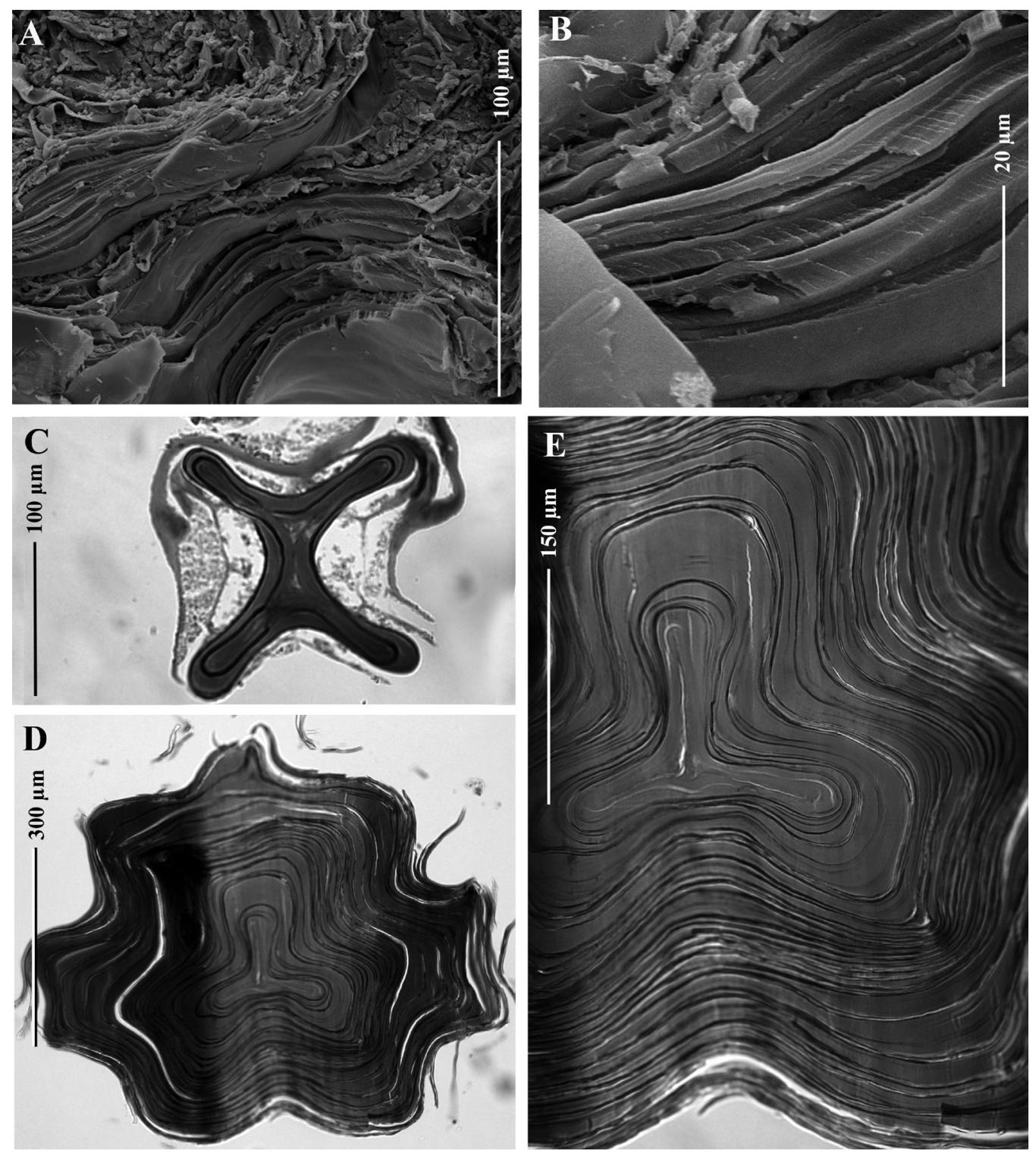

FIG. 8. - Dendrobrachia bonsai $\mathrm{n}$. sp., BEIM(CRO-0019): SEM photos, A, cross section of axis from basal stem showing multilayer structure; B, detail from A showing layers 1.5-4.3 um thick; histological sections: $C$, transversal section close to the tip of a twig, showing an X-shaped nucleus and an additional layer, note also longitudinal channels (indicated with arrows) and the distinct limits between nucleus and layer; $\mathrm{D}$, transversal section from a stem close to the basal holdfast, note the multilayered structure of the axis, and a Y-shaped central core; E, detail from D, showing about 25 layers.

nated by abundant and diverse sessile fauna (sponges and cnidarians).

In coral, chimneys and sandstone samples, obtained by dredging and TV-grab, the two most important groups of benthic cnidarians were present in different numbers of species $(7,9$, and 3 species of anthozoans, and 15, 16, and 4 species of hydrozoans, for each habitat respectively). Among the most frequent are the anthozoan Muriceides sp., and the hydrozoan Lafoeidae (Acryptolaria conferta and Zygophylax biarmata) and Plumulariidae (Polyplumaria flabellata). The structural complexity provided by the hard substrata, the dead coral framework and the living cnidarians host a wealth of mobile organisms such as polychaetes, crustaceans and echinoderms. The polychaete assemblage (17, 25 and 6 species in coral, chimneys and sandstones respectively) is dominated by highly mobile predators (e.g. Lumbrineridae, Nereididae, Phyllodocidae and Syllidae) and the crustacean assemblage (23, 24 and 6 species in corals, chimneys and sandstones respectively) is dominated by small-sized amphipods and isopods. Molluscs and ophiuroids are much less diverse with two recurrent species, the bivalve Bentharca asperula, which frequently occurs attached to chimneys and sandstones, and the ophiuroid Amphipholis squamata, which occurs entangled in the coral framework and inside fissures of the carbonates. 


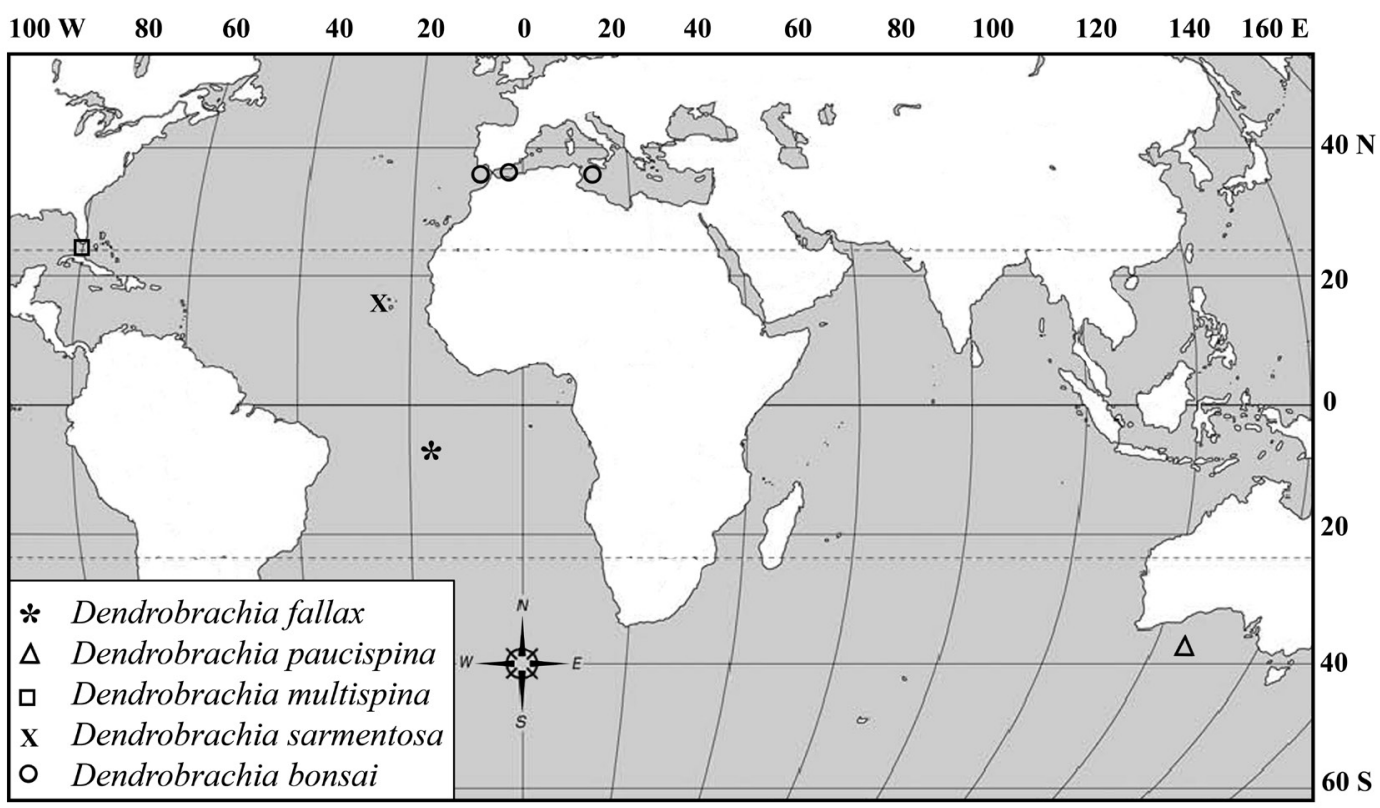

FIG. 9. - Known records of all described Dendrobrachia species.

Remarks. Dendrobrachia bonsai $\mathrm{n}$. sp. is clearly distinguishable from the other species in the genus by its delicate and small colonies, as well as by the reduced number of longitudinal ridges in branches and branchlets. In addition, the spine ornamentation on these ridges is practically absent in distal branch orders; $D$. bonsai $\mathrm{n}$. sp. is -in this latter featuremore similar to the south-eastern Australian species Dendrobranchia paucispina (see Opresko and Bayer, 1991) than to its Atlantic congeners. Some short specimens-in this species those colonies of about $30 \mathrm{~mm}$ in length - show a spination higher than that of fully developed specimens, especially on the basal stem, where in some places two rows of spines can be observed on a single axial ridge, a similar situation to that observed for D. multispina. However, in this latter species the spines are densely placed, the spines of the two series rise close to one another, and reach up to $0.4 \mathrm{~mm}$. In D. bonsai n. sp., the spines are not densely placed, both series of spines (when present) on the same ridge are widely separated by a smooth space (as part of the natural process of the formation of additional ridges already discussed), and do not reach more than $0.05 \mathrm{~mm}$.

Additional details can be observed in Table 1 and selected characters used in the key to species.

\section{DISCUSSION}

With the description of Dendrobrachia sarmentosa n. sp. and $D$. bonsai, five species are now known in the genus (Fig. 9). The type species, D. fallax, is only known from the south-central Atlantic. Of the two species described by Opresko and Bayer (1991), one comes from south Florida, D. multispina, and the other one comes from south-western Australia, D. paucispina. In this paper we add one from off Cape Verde Islands, $D$. sarmentosa $\mathrm{n}$. sp., and another one with the widest distribution known in the genus, D. bonsai, present in the Gulf of Cadiz and the western Mediterranean (Alboran Sea, and the Strait of Sicily).

Dendrobrachia species mainly inhabit the continental slope, from 230 to $1080 \mathrm{~m}$ depth. Dendrobrachia bonsai $\mathrm{n}$. sp. is the best represented species in number of known colonies and localities, and it also has the widest bathymetric presence.

The traditional taxonomic characters used in the systematics of most octocorals are not useful in this genus due to the lack of calcareous sclerites, and a set of features from the axis structure are the only source of characters used in the taxonomy of this group. The lack of calcareous sclerites and the structure of the proteinaceous axis have also been used to establish some crysogorgiid affinities, especially with Trichogorgia (Opresko and Bayer, 1991). Further molecular studies could probably help in the assignation of Dendrobrachia to a particular family. For the moment, the results of the two molecular analyses carried out (both based on the same material from $D$. paucispina) are quite confusing. In the first one, Berntson et al. (1999) based on $18 \mathrm{~S}$ rDNA, only concludes the octocoral nature of D. paucispina, branched with the species Umbellula sp., Narella bowersi, and Lepidisis sp. [Pennatulacea, and Calcaxonian gorgonians (Primnoidae and Isididae) respectively]. In the second of the published contributions based on molecular comparisons within the subclass Octocorallia using nuclear 18S rRNA (Berntson et al., 2001), Dendrobrachia paucispina showed a close affinity with the genera Corallium and Paragorgia (both dimorphic Scleraxonian gorgonians, Cor- 
alliidae and Paragorgiidae respectively). Currently the genus Dendrobrachia is isolated in a family by itself, Dendrobrachiidae, because of the unique nature of the axial skeleton.

The following key to known Dendrobrachia species is based on selected characters from Table 1 and the respective original descriptions, trying to take into account the variability shown by the known material in each described species:

\section{Key to Dendrobrachia species}

1. Distal branchlets with 5 or fewer axial ridges ...... 2

- Distal branchlets usually with 6 or more axial ridges

2. Distal branchlets $0.4-0.5 \mathrm{~mm}$ in diameter, consistently with 5 axial ridges throughout the corallum (larger branch observed $1.4 \mathrm{~mm}$ in diameter); larger branches with 2 (or more) rows of spines on each axial ridge, in these cases axial spines can reach up to $0.4 \mathrm{~mm}$ in length

D. multispina Opresko and Bayer, 1991

- Distal branchlets 0.15-0.17 mm in diameter, consistently with 4 axial ridges, the number of ridges increases with axis diameter [about 14 axis ridges in the maximum axial diameter measured $(0.55 \mathrm{~mm}$ at basal stem)]; larger branches smooth or with one row of scarce axial spines less than $0.03 \mathrm{~mm}$ long, when 2 rows are present (rarely observed, on the basal stem), axial spines can reach up to $0.05 \mathrm{~mm}$ in length D. bonsai n. sp.

3. Distal branchlets with axial spines up to $0.10 \mathrm{~mm}$ long, while ridges on axis of more than $2 \mathrm{~mm}$ in diameter can have axial spines up to ca. $0.5 \mathrm{~mm}$ long (axial spines up to $0.25 \mathrm{~mm}$ in axis of $1 \mathrm{~mm}$ in diameter).... D. fallax Brook, 1889

- Distal branchlets with axial ridges smooth, or with low elevations, or short spines not longer than 0.02 $\mathrm{mm}$, while ridges on axis of more than $2 \mathrm{~mm}$ in diameter can have axial spines up to $0.25 \mathrm{~mm}$ long (axial spines up to $0.15 \mathrm{~mm}$ in axis of $1 \mathrm{~mm}$ in diameter)

\section{4}

4. Corallum slender in appearance, stem diameter / height ratio 1.1-1.7 (in \%), branches and branchlets upward directed, forming an angle $>45^{\circ}$ with their respective main stem

D. paucispina Opresko and Bayer, 1991

- Corallum robust in appearance, stem diameter / height ratio 2.5 (in \%), branches and branchlets often decumbent, forming a right angle or wider angle $\left(80-120^{\circ}\right)$ with their respective main stem .... D. sarmentosa n. sp.

\section{ACKNOWLEDGEMENTS}

The authors wish to acknowledge Michèle Bruni, curator of the Musée océanographique de Monaco, for the loan of the Dendrobrachia colony studied by Thomson. We are also in debt to Emma Sherlock, curator of invertebrates at the Natural History Museum in London, for providing the photographs of the Dendrobrachia fallax type material in Figure $1 \mathrm{~A}$. We also thank Dr. Helmut Zibrowius for providing the specimens collected during the MARCOS cruise (Marco Taviani, cruise leader), as well as many comments and suggestions on Mediterranean Dendrobrachia specimens during the elaboration of this paper.

This research has been partially funded by the Acciones Integradas Hispano-Portuguesas research program (HP-2004-0048) / Cooperação Bilateral Luso-Espanhola, Acções Integradas 2005 (E82-05) of the Spanish Ministry of Education and Science and Conselho de Reitores das Universidades Portuguesas. The authors wish to acknowledge the co-chief scientists Luís Pinheiro (Departamento de Geociências, Universidade de Aveiro) and Michael Ivanov (Moscow State University), the scientific parties and crew of the RV Prof. Logachev for the TTR12 and TTR14 cruises (Training Through Research Programme, IOCUNESCO). We are indebted to the anonymous referees and Scientia Marina Editor for their valuable comments and suggestions.

\section{REFERENCES}

Bayer, F.M., M. Grasshoff and J. Verseveldt. - 1983. Illustrated trilingual glossary of morphological and anatomical terms applied to Octocorallia. E.J. Brill/Dr. W. Backhuys, Leiden.

Berntson, E.A., S.C. France and L.S. Mullineaux. - 1999. Phylogenetic relationships within the Class Anthozoa (Phylum Cnidaria) based on nuclear $18 \mathrm{~S}$ rDNA sequences. Mol. Phyl. Evol., 13(2): 417-433.

Berntson, E.A., F.M. Bayer, A.G. McArthur and S.C. France. 2001. Phylogenetic relationships within the Octocorallia (Cnidaria: Anthozoa) based on nuclear 18S rRNA sequences. Mar. Biol., 138: 235-246.

Brook, G. - 1889. Report on the Antipatharia. Rept. Sci. Res. Voyage Challenger, Zool. 32: i-vi + 1-222.

Magalhães, V.H. - 2007. Authigenic carbonates and fluid escape structures in the Gulf of Cadiz. Ph.D. thesis, Univ. Aveiro.

Opresko, D.M. and F.M. Bayer. - 1991. Rediscovery of the enigmatic coelenterate Dendrobrachia, (Octocorallia: Gorgonacea) with description of two new species. Trans. R. Soc. S. Aust., 114(1): 1-19.

Thomson, J.A. - 1910. Note on Dendrobrachia fallax Brook, a rare and remarkable antipatharian. J. R. Microscop. Soc., 1910: 142-143.

Zibrowius H. and M. Taviani. - 2005. Remarkable sessile fauna associated with deep coral and other calcareous substrates in the Strait of Sicily, Mediterranean Sea. In: Freiwald A. and J.M. Roberts (eds), Cold-water Corals and Ecosystems, pp 807-819. Springer-Verlag, Berlin Heidelberg.

Scient. ed.: M.P. Olivar.

Received May 27, 2009. Accepted October 20, 2009.

Published online May 10, 2010. 